Professor Tayfur BAYAT, PhD

E-mail: tayfur.bayat@inonu.edu.tr

Department of Economics, Inonu University, Lecturer Seyhun TUTGUN, PhD Candidate (Corresponding Author)

E-mail: stutgun@beu.edu.tr

Hizan Vocational School, Bitlis Eren University

Associate Professor İzzet TAŞAR, PhD

E-mail: itasar@firat.edu.tr

Department of Economics, Frrat University

\title{
SYMMETRIC AND ASYMMETRIC EFFECTS OF MONETARY POLICY SHOCKS ON OUTPUT IN BRICS COUNTRIES: EVIDENCE FROM HIDDEN PANEL COINTEGRATION
}

Abstract: Monetary policy and its possible effects on total output has been discussed both theoretically and empirically by many economic schools within the framework of economic theory. This study questions the symmetric and asymmetric effects of monetary policy shocks on output in the BRICS countries for the period of 1997-2019 were analyzed using hidden panel data method. According to the empirical analysis results, monetary policy does not have a symmetrical effect on output. Asymmetric effects on the other hand valid from negative and positive shocks of monetary policy to positive and negative shocks of output respectively in the short and also in the long run.

Keywords: Monetary Policy, Symmetric Effect, Asymmetric Effect,

BRICS.

JEL Classification Codes: E52; E58; E60

\section{Introduction}

Monetary policy is quite important for countries to be able to control their economic indicators and also to sustain the increase in output. Conceptually, it refers to money supply and interest control to achieve predetermined macroeconomic targets such as increasing productivity and employment, as well as controlling the price level. The fact that they are easy to control has an important role in creating a confident economic environment. There are many studies in the literature. According to Keynesian economics, expansionary policy, Decline of short-term lending interest rate will or effect the long-term interest rates. It will indirectly increase the amount of output via the increase in investments. On the

DOI: $10.24818 / 18423264 / 55.4 .21 .14$ 
subject, Lucas (1972) emphasizes that only unexpected monetary policy practices have an effect on production. Friedman (1968), likening monetary policy to a rope, stated that inflation can be halted which will not stop the recession. Claiming the opposite, Garcia and Schaller (2002) concluded in their studies that it is more efficient during recession period.

Analysing monetary policy shocks and its effect on real economic variables have been important but not a new issue in recent years. Monetary policy shake ups are tested mainly with short-term interest rates, output, employment, prices.

It has been revealed that production, employment and real wages are not affected by monetary policy shocks, however nominal variables and also price level are seriously affected. Monetary policy shocks changes the economic structure, either in a constricting or expanding way. The contractionary shocks increase financial fragility on the economy and increase the share of loans in GDP. This situation results in an increase in the financial ratio, which is expressed as the debt / domestic funds ratio, for companies. Short term monetary expansionary boosts production, inflation rate, prices, housing units (resurgence of the housing market), money supply and non-borrowing reserves. Conversely, the contractionary policy has a greater effect than the expansionary monetary policy. While positive money supply shocks affects prices more than negative money supply shocks, negative money supply shocks have higher effect on aggregate demand than positive shocks, based on the "pushing on a string" representing the asymmetric effects of money on output (Karras and Stokes, 1999). In addition, some findings concluded that the effect of negative monetary shocks is stronger on output during high growth periods with comparison to low growth periods (Thoma, 1994).

BRICS countries trade volumes has a big impact in the world economy. These countries were first included in the literature as BRIC, following a decade, became BRICS with the participation of 2011 South Africa. The rich natural resources of BRICS countries, approximately $43 \%$ of the world's population and constituting approximately $1 / 3$ of the world economy in terms of economy increase the importance of the community. There are reports that claim China will become the largest economy and the rest of BRICS countries in the future can be the world largest 10 economies in 50 years.

Especially the financial crisis experienced in the 2007-2009 period started in the USA and affected the whole world caused significant decreases in the amount of total output. This special period was such a "chance" to some developing countries to create the necessary robust macroeconomic environment and policies. BRICS countries are able to avoid external shocks compared to developed countries and have a faster recovery period thanks to their strong foreign exchange reserves and increasing domestic demand. In this period, Brazil and Russia, whose financial integration levels were higher, were more affected by the crisis than other BRICS countries. Following the crises, expansionary monetary policies applied in all countries by taking steps in the name of fiscal expansion during this period. In addition, increasing public expenditures and the implementation of interest policies 
Symmetric and Asymmetric Effects of Monetary Policy Shocks on Output in BRICS Countries: Evidence from Hidden Panel Cointegration

to increase investments have resulted positive growth figures more rapidly. In the heart of monetary policies, central banks in this period take similar steps in line with the monetary policy instruments, frameworks and objectives. Central Banks in BRICS countries focused on inflation targeting and interest rates. Brazil used Selic interest rate as tool in inflation targeting, that method roughly used the interbank and market interest rates as reference. In line with inflation targeting in Russia, uses interest rate to keep the inflation rate around $4 \%$. By realizing its inflation targeting with a five-year planning, India mainly uses the repo and repo interest rate. China follows classical monetary policy instruments and other policy instruments determined by the Council of State. South Africa, which has switched to inflation targeting after 2000 , uses interest rates.

This study investigates the symmetrical and asymmetrical effects of monetary policy shocks experienced in BRICS countries on total output. While examining these effects, unlike the classical VAR analysis, this study is new for the literature. It is handled with the hidden cointegration analysis method. İnformation on the relationship between the variables are mentioned is provided in the introduction. Then in the literature section, the methodological review of the subject has been supported by many other related studies. Finally in the empirical results section, the symmetrical and asymmetrical effects of monetary policy shocks on output are examined with the help of Panel Unit Root Test, Panel Hidden Cointegration Analysis and Panel VECM Causality Test.

\section{Literature Review}

Recent researches in this subject are summarized in this section. monetary policy shocks vary in different situations, and can affect output either symmetrically or asymmetrically. Some states the reasons for monetary policy asymmetry depends on the type of monetary policy (expansion or contraction) and whether monetary shocks are expected or not. There are examples that supports the symmetrical relation from monetary policy shocks to output and on reverse. Monetary policy shocks are described as either constricting or expanding in the literature. While decreasing interest rates is "expansionary" to encourage investments in the economy and increase economic activities, increasing interest rates in order to ensure non-inflationary growth and prevent inflationary pressures appears as a "contractionary" policy.

According to literature, same economic policy may have different results; negative (expansionary) monetary policy shock has positive effects on output and vice versa, positive (contractive) policy shock decreases economic growth and negatively affects output. There are also studies that supports the effect of positive (contractive) monetary policy shocks on output is higher than negative (expansionary) monetary policy shocks. Contrary to these results, there are some studies that the effects of negative (expansive) monetary shocks are greater than positive (contractive) shocks.

To sum up the literature in terms of results; most argues that there is a relationship between monetary policy shocks and total output. For some, monetary 
policy shocks increase total output and it is emphasized that these shocks are caused by domestic rather than external shocks. In addition to the positive effects of monetary policy on output, the expected shocks have a higher effect on output than unexpected shocks.

Some others underline the weak relation between monetary policy shocks on output. The reasons can be explained under two headings. First, important monetary transmission channels are not fully functional or weak, while the second factor can be expressed as the weak structure of credit markets.

\section{Data Set, Methodology and Empirical Results}

The symmetrical and asymmetric effects of monetary policy shocks were tested in the context of Brazil, Russia, India, China and South Africa economies with the method of the hidden panel data for analysis and 1997 to 2019 annual data is considered. Real interest rates (RINT) and gross domestic product (GDP) are used as variables. The World Bank online data pool was used in order to obtain the variables. The variables used in the analysis were segregated into positive and negative components by applying the separation method developed by Granger and Yoon (2002). Im et al(2003, IPS) and Levin et all. (2002, LLC) unit root tests are applied to each asymmetrical variable.

Results obtained from the unit root test, the cointegration test developed by Kao (1999) and Kao and Chiang (2000) was conducted to see the effect of real interest on output. Finally, panel hidden vector autoregression (PVAR) and error correction (PVEC) causality tests developed by Hatemi-J and Irandoust (2012) are implemented. LLC (2002) and IPS (2003) panel unit root tests by Dickey-Fuller $(1979,1981, \mathrm{DF})$ unit root test included in the time series analysis. The panel is autoregressive AR (1) process is as $y_{i t}=\rho_{i} y_{i t-1}+X_{i t} \delta_{i}+\varepsilon_{i t}$. In the formula, $\mathrm{i}$ denotes the horizontal dimension and t time dimension, error term is distributed with zero mean and constant variance. LLC (2002) unit root test, the autoregressive ( $\rho$ ) coefficient for all horizontal sections is assumed to be homogeneous, and in the IPS (2003) unit root test the autoregressive coefficient is assumed to be heterogeneous. In the IPS $(2003)$ unit root test, the DF $(1979,1981)$ unit root test is performed for each cross section and the arithmetic average of the obtained $\tau$ test statistics is calculated. While IPS (2003) panel unit root test requires balanced panel, LLC (2002) does not require a balanced panel in unit root test. Null hypothesis of both panel unit root tests is the variable with its unit root $(\rho i=1)$. Table 1 reflects the unit root test results of the variables "real interest rates" and "gross domestic product" as raw data and also after divided into components by the test developed by Granger and Yoon (2002). 
Symmetric and Asymmetric Effects of Monetary Policy Shocks on Output in BRICS Countries: Evidence from Hidden Panel Cointegration

\section{Table:1. LLC (2002) and IPS (2003) Panel Unit Root Test Results}

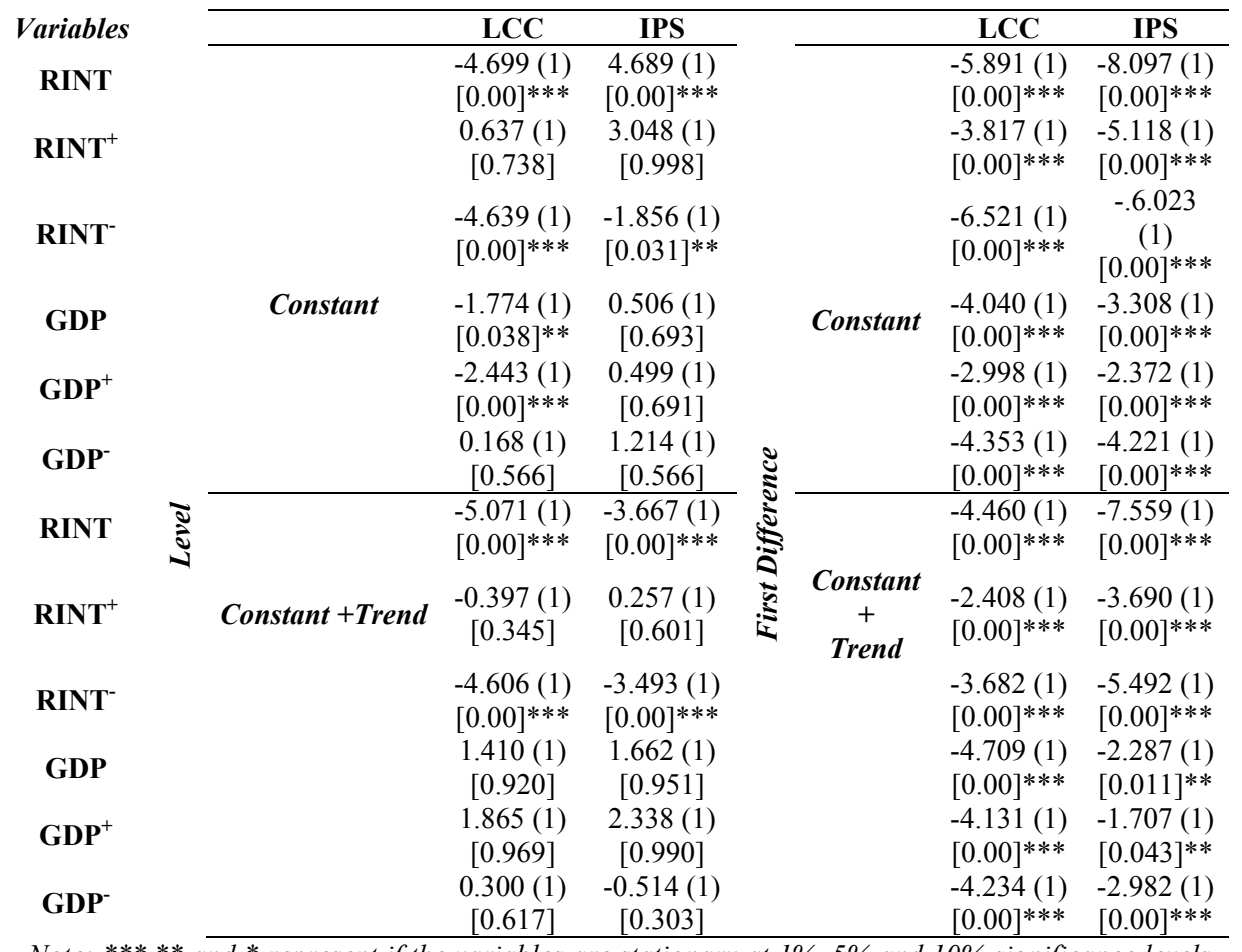

Note: $* * *, * *$ and $*$ represent if the variables are stationary at $1 \%, 5 \%$ and $10 \%$ significance levels,

respectively.

Avoiding unit root, first difference is considered for all variables. They are all stationary when the first difference is considered. Kao (1999) and Kao and Chiang (2000) cointegration tests are performed based on the test process $^{1}$ in Hatemi-J (2020) study. Hatemi-J (2009) states that two stationary variables which are first order are separated as follows;

$$
\begin{gathered}
y_{i t}=y_{i, t-1}+e_{i 1, t}=y_{i, 0}+\sum_{J=1}^{t} e_{i 1, j} \\
x_{i t}=x_{i, t-1}+e_{i 2, t}=x_{i, 0}+\sum_{J=1}^{t} e_{i 2, j}
\end{gathered}
$$

\footnotetext{
${ }^{1}$ When the articles on which panel data method is applied are considered, empirical analysis process of study, unit root, cointegration and causality tests should be performed according to whether there is cross-section dependency or not. However, in this study, based on the study of Hatemi-J (2020), IPS (2003) and LLC (2002) 1st generation unit root tests, does not account for the cross-sectional dependency, and Kao (1999) cointegration test are hired.
} 
Tayfur Bayat, Seyhun Tutgun, Izzet Taşar

Where " $\mathrm{m}$ " is the number of cross sections and error term with independent identical distribution. The $e_{i 1, t}^{+}=\operatorname{Max}\left(\mathrm{e}_{i 1, t}, 0\right)$ and $e_{i 2, t}^{+}=\operatorname{Max}\left(\mathrm{e}_{i 2, t}, 0\right)$ positive shocks, $e_{i 1, t}^{-}=\operatorname{Min}\left(\mathrm{e}_{i 1, t}, 0\right)$ and $e_{i 2, t}^{-}=\operatorname{Min}\left(\mathrm{e}_{i 2, t}, 0\right)$ random shocks in negative error term are determined. Thus, positive components including the error term; $y_{i 1, t}^{+}=y_{i, 0}^{+}+e_{i 1, t}^{+}=y_{i, 0}+\sum_{J=1}^{t} e_{i 1, \mathrm{j}}^{+}$and $y_{i 1, t}^{-}=y_{i, 0}^{-}+e_{i 1, t}^{-}=y_{i, 0}+\sum_{J=1}^{t} e_{i 1, \mathrm{j}}^{-}$also negative components $\quad$ are $\quad x_{i 1, t}^{+}=x_{i, 0}^{+}+e_{i 2, t}^{+}=x_{i, 0}+\sum_{J=1}^{t} e_{i 2, \mathrm{j}}^{+} \quad$ and $x_{i 1, t}^{-}=x_{i, 0}^{-}+e_{i 2, t}^{-}=x_{i, 0}+\sum_{J=1}^{t} e_{i 2, \mathrm{j}}^{-}$. According to that, the cointegration relation between components of $y_{i, t}$ variable and $x_{i, t}$ variable is;

$$
\begin{gathered}
y_{i, t}^{+}=\alpha_{i}^{+}+\beta_{i}^{+} x_{i, t}^{+}+e_{i, t}^{+} \\
y_{i, t}^{-}=\alpha_{i}^{-}+\beta_{i}^{-} x_{i, t}^{-}+e_{i, t}^{-}
\end{gathered}
$$

If $e_{i, t}^{+}$is stable, a cointegration relationship between positive shocks exists and if $e_{i, t}^{-}$is stable, there is a cointegration relationship between negative shocks. The cointegration test DF $(1979,1981)$ developed by Kao (1999) and Kao and Chiang (2000) is a parametric test based on the unit root test. The long-term relationship between $\mathrm{x}_{\mathrm{it}}$ and $\mathrm{y}_{\mathrm{it}}$ variables in $y_{i t}=x_{i t}^{\prime} \beta+z_{i t}^{\prime} \gamma+\varepsilon_{i t}$ model depends on whether the error term $\varepsilon_{\mathrm{it}}$ is stationary or not. The null hypothesis of the test indicates the inexistence of cointegration for all horizontal sections and the alternative hypothesis indicates cointegration for all horizontal sections. ${ }^{2}$

\section{Table:2. Kao (1999) Panel Cointegration Test Results}

\begin{tabular}{ccc}
\hline & $\begin{array}{c}\text { Augmented Dickey-Fuller } \\
\text { t Statistic }\end{array}$ & Probability Value \\
\hline $\mathrm{GDP}=\mathrm{RINT}$ & -0.492 & 0.311 \\
$\mathrm{GDP}^{+}=\mathrm{RINT}^{+}$ & -1.175 & 0.119 \\
$\mathrm{GDP}^{+}=\mathrm{RINT}^{-}$ & -2.412 & $0.00^{* * *}$ \\
$\mathrm{GDP}^{-}=\mathrm{RINT}^{+}$ & -3.327 & $0.00^{* * *}$ \\
$\mathrm{GDP}^{-}=\mathrm{RINT}^{-}$ & -0761 & 0.223 \\
\hline Note & $* * * * *$ and & $*$ represent if the variables are stationary at $1 \%, 5 \%$ and $10 \%$ significance levels,
\end{tabular}

respectively.

${ }^{2}$ Plase check Kao (1999) and Hatemi J. (2009) for test details. 
Symmetric and Asymmetric Effects of Monetary Policy Shocks on Output in BRICS Countries: Evidence from Hidden Panel Cointegration

Table 2 shows results of cointegration relationship between real interest rate and gross domestic product. According to these results, a long-term relationship between the positive component of the gross domestic product (increase) and the negative component (decrease) of the real interest rate at the $1 \%$ significance level. Also there is a long-term relationship between the negative component of the gross domestic product (decrease) and the positive component (increase) of the real interest rate at the $1 \%$ significance level. Interest rate is a key factor that has serious implications for the macro economic variables such as savings rates, investment and balance of payments accounts. Especially a very important determinant for the interest of global funds in the domestic financial assets. The channels for real interest rates to affect gross domestic product are the change in investment and total demand depending on interest rates (Taylor, 1999), as well as the increase or decrease in production due to the volatility (Asgharpur, Kohnehshahri and Karami, 2007: 2) created in production costs.

The panel error correction model (PVEC) is formed by adding the error correction term to panel vector auto regression (PVAR) model. PVEC model regression is obtained from

$$
\Delta R I N T=\delta_{1 i}+\sum_{p=1}^{k} \delta_{11 i p} \Delta R I N T_{i t-p}+\sum_{p=1}^{k} \delta_{12 i p} \Delta G D P_{i t-p}+\phi_{1 i} \hat{\varepsilon}_{i 1-1}+v_{1 i t} .
$$

In the panel VAR model, the null hypothesis is $\sum_{p=1}^{k} \delta_{12 i p} \Delta R I N T_{i t-p}=0$ and suggests "there is no causality from the real interest rate to the gross domestic product in short run". Alternative hypothesis is $\sum_{p=1}^{k} \delta_{12 i p} \Delta R I N T_{i t-p} \neq 0$ and suggests "there is causality from real interest rate to gross domestic product in the short run". The null hypothesis in the PVEC model is $\phi_{1 i} \hat{\varepsilon}_{i 1-1}=0$ and suggests "there is no Granger causality from long real interest rate to gross domestic product".

Table:3. Panel VAR and Panel VECM Causality Test Results

\begin{tabular}{ccc}
\hline & $\begin{array}{c}\text { PVAR } \\
\text { Short Run }\end{array}$ & \multicolumn{1}{c}{$\begin{array}{c}\text { PVEC } \\
\text { Long Run }\end{array}$} \\
\hline RINT $\neq>$ GDP $_{\mathbf{R I N T}^{+} \neq>\mathbf{G D P}^{+}}$ & $4.438(0.217)$ & $-0.000609[-0.288]$ \\
RINT $^{-} \neq>\mathbf{G D P}^{+}$ & $3.411(0.332)$ & $-0.084897[-2.563]^{* *}$ \\
RINT $^{+} \neq>\mathbf{G D P}^{-}$ & $9.418(0.024)^{* *}$ & $-0.175777[-3.689]^{* * *}$ \\
RINT $^{-} \neq>\mathbf{G D P}^{-}$ & $12.774(0.00)^{* * *}$ & $-0458826[-4.458]^{* * *}$ \\
\hline Notes $:$ The figures which is & $6 * * * * *, * .079)^{*}$ & $-0.444000[-5.167]^{* * *}$ \\
\hline
\end{tabular}

Findings revealed that there is a causality relationship from the negative component (decrease) of real interest rate to positive component (increase) of the 
gross domestic product at the significance level of 5\% in short run. In short term, decreases in real interest rates will positively affect consumption and investment decisions, will induce to an increase in gross domestic product. In addition, a causality relationship from the positive component (increase) of the real interest rate to the negative component (decrease) of the gross domestic product at the $1 \%$ significance level is suggested according to test results. The increase in short-term interest rates will cause individuals to reduce their current consumption and increase their savings (Taylor, 1999), and thus to decrease gross domestic product, since the substitution effect is always negative. In addition, interest rates increases will cause an increase in the debt burden of investors and banks, a problem of repayment of loans and a slowdown in cash flow, thus interrupting economic activities. Besides, the increase in real interest rates affects the financial markets negatively because of the fact that interest rates are higher mostly in bad economic environment. Due to the high risk of loans given in this period, the banking sector was negatively affected (Pill, 1997), leading to financial crises, leading to a decline in gross domestic product. Finally, it has been revealed that there is a causality relationship from the negative component (decrease) of the real interest rate to the negative component (decrease) of the gross domestic product at $10 \%$ significance level in the short run. The reason for that causality relation is due to the relationship between short term capital movements and interest rates. It is possible to say that the increase in interest rates in China, one of the developing BRICS countries we have examined, tight monetary policy (interest rate hike) will draw a lot of hot money to China for high returns in the beginning. However, interest rates boost lessens investment in the economy, so investment income decreases, and this causes reduction in international capital outflow (Jia and Ren, 2017).

It has been demonstrated that similar results are valid in Brazil, Russia (Hofman et al., 2007) and India (Seth and Varma, 2007). In long run, causality from all components of real interest rate to all components of gross domestic product. As stated above, real interest rates affect the economy through consumption, investment and savings channels. Considering that interests are the main determinants of investments especially in developing BRICS countries and the effect of investments on the gross domestic product in many developing countries, the long-term relationship between the variables is more clear. The decrease (increase) in real interest rates leads to an increase (decrease) in the gross domestic product through investment and consumption channels in the long run. According to the findings, the fact of inexistence of long-term relationship between real interest rates and gross domestic product supports the results of the study conducted by King and Levine (1993) on developed countries.

To summarize the findings of our study in general, first of all, unit root analyses were conducted in terms of the accuracy of the methods. We hired two variables for the tests, first one is the real interest rate to illustrate the shocks in the monetary policy and the second one is the gross domestic product to represent the output. The series segmented into positive and negative components by applying the separation method developed by Granger and Yoon (2002). Unit root test 
Symmetric and Asymmetric Effects of Monetary Policy Shocks on Output in BRICS Countries: Evidence from Hidden Panel Cointegration

developed by Im et al. (2003, IPS) and Levin et all (2002, LLC) was performed on each asymmetric parts. In the form of raw data, it is concluded that the real interest rates are stationary at the level, and the gross domestic product is stationary in the model with 5\% significance level and constant model in the LCC (2002) test. While the negative component of real interest rates is also stationary at the level, all other situations are seen to become stationary at the first difference. After the unit root test, Kao (1999) and Kao and Chiang (2000) cointegration tests were performed based on the test process in Hatemi-J (2020).

The cointegration test results proves a long-term relationship between positive component of gross domestic product (increase) and the negative component (decrease) of the real interest rate and between the negative component of the gross domestic product (decrease) and the positive component (increase) of the real interest rate.

Finally, panel hidden vector autoregression (PVAR) and error correction (PVEC) causality tests developed by Hatemi-J and Irandoust (2012) are performed. The results of short-term causality test, the causality relationship from negative component (decrease) of the real interest rate to the positive component (increase) of the gross domestic product supports the argument that the gross domestic product can be increased through the increase in investment and consumption.

Another result is that there is a causality relationship from the positive component in real interest rate to negative component (decrease) of the gross domestic product. In addition, it can be expressed that there is a causality relationship from all components of real interest rate to all components of gross domestic product in long run.

\section{Conclusion and Policy Recommendations}

Many factors such as exchange rate regime, price stability, structure of capital mobility, expectations of economic decision-making units, public budget balance and political stability are important on the effectiveness of monetary policy. Symmetric and asymmetric effects of monetary policy shocks in the economies of Brazil, Russia, India, China and South Africa for the period 19972019 were tested via the hidden panel data method. Real interest rate variable is hired to represent monetary policy shocks and gross domestic product variables are hired for total output. Two different data were considered in this study. The symmetrical effect is examined as raw data and then the asymmetric relationship is examined after applying the separation method developed by Granger and Yoon (2002). As the raw data, the real interest rate is stationary at the level and the gross domestic product is stationary in the first difference, assuming long memory. The negative component of the real interest rate variable is stationary at the level value whereas the positive component is stationary in the first difference. Both components of gross domestic product are the first aware stationary. When the analyse period is considered, the cyclical fluctuations in total output due to economic crises and nominal interest rates adapted to these fluctuations, results in 
accordance with the economic theory. Although there is no symmetrical relationship in the cointegration test developed by Kao (1999) and Kao and Chiang (2000), there is a long-term relationship between the positive and negative shock of the real interest rate and the negative and positive shock of the output, respectively.

According to the panel vector autoregression results, there is an asymmetric causality from positive and negative monetary policy shock to positive shock of gross domestic product, from positive monetary policy shock to negative shock of gross domestic product in the short run. On the other hand, according to the panel error correction model, there is a long-term asymmetric causality from positive and negative shocks of monetary policy to positive and negative shocks of total output.

Depending on the preference of the exchange rate regime and the sensitivity of capital movements to the interest rate, the expansionary monetary policy increases domestic investments by lowering the domestic interest rate. Increasing real output increases the demand for foreign goods and services. With the decrease in the ratio of exports to imports, the demand for foreign currency increases. In other countries except China, under the assumption of floating exchange rate, the national currency depreciates and the ratio of exports to imports rises again. As a result, the expansionary monetary policy realized with the increase in money supply creates an asymmetrical effect on real output. In addition, there is no symmetrical causality relationship between monetary policy and output in either the short or long run. When symmetrical and asymmetrical results are evaluated as a whole, the claim of Keynesian economics "monetary policy has an effect on real output" works based on two assumptions; 1) the unemployment in the economies 2 ) the volatility in circulation of money. On the contrary, the hypothesis of classical economics that the monetary policy affects only the general level of prices and has no effect on real output is not valid according to test results. In future studies, time delays of the impact of monetary policy shocks on real activity and prices can be measured and the transmission mechanisms triggered by these shocks can be examined. In future studies, the impact of monetary policy shocks on real activity and prices can be measured in terms of time delays and also the transmission mechanisms triggered by these shocks can be examined.

\section{REFERENCES}

[1]Asgharpur, H., Kohnehshahri, L. A., \& Karami, A. (2007), The Relationships between Interest Rates and Inflation Changes: An Analysis of Long-Term Interest Rate Dynamics in Developing Countries. Paper presented at International Economic Conference on Trade and Industry;

[2]Dickey, D. A. \& Fuller, W. A. (1979), Distribution of the Estimators for Autoregressive Time Series with a Unit Root. Journal of the American Statistical Association, 74(366a), 427-431. https://doi.org/10.1080/01621459.1979.10482531 
Symmetric and Asymmetric Effects of Monetary Policy Shocks on Output in BRICS Countries: Evidence from Hidden Panel Cointegration

[3]Dickey, D. A. \& Fuller, W. A. (1981), Likelihood Ratio Statistics for Autoregressive Time Series with a Unit Root. Econometrica: Journal of the Econometric Society, 1057-1072. https://doi.org/10.2307/1912517;

[4]Friedman M. (1968), The Role of Monetary Policy. American Economic Review 58(1), 1-17. https://doi.org/10.4324/9780203443965.ch7;

[5] Garcia, R. \& Schaller, H. (2002), Are the Effects of Monetary Policy

Asymmetric?. Economic Inquiry, 40(1), 102-119.

https://doi.org/10.1093/ei/40.1.102;

[6]Granger, C. W. \& Yoon, G. (2002), Hidden Cointegration. Department of

Economics Working Paper. University of California. San Diego.

https://doi.org/10.2139/ssrn.313831;

[7]Hatemi-J, A. (2009), The International Fisher Effect: Theory and Application. Investment Management and Financial Innovations, (6, Iss. 1), 117121;

[8]Hatemi-J, A. (2020), Hidden Panel Cointegration. Journal of King Saud University-Science, 32(1), 507-510. https://doi.org/10.1016/j.jksus.2018.07.011;

[9]Hatemi-J, A. \& Irandoust, M. (2012), Asymmetric Interaction between Government Spending and Terms of Trade Volatility: New Evidence From Hidden Cointegration Technique. Journal of Economic Studies, 39(3), 368-378. https://doi.org/10.1108/01443581211245937;

[10]Im, K. S., Pesaran, M. and Shin, Y. (2003), Testing for Unit Roots in Heterogeneous Panels. Journal Of Econometrics, 115, Ss.53

74. https://doi.org/10.1016/s0304-4076(03)00092-7;

[11]Jia, X. \& Ren, Y. (2017), The Impact of Institutional Factors and Capital Market Openness on Short-Term International Capital Flow. In 2017 4th International Conference on Industrial Economics System and Industrial Security Engineering (IEIS) (pp. 1-6). IEEE. https://doi.org/10.1109/ieis.2017.8078613;

[12]Kao, C. (1999), Spurious Regression and Residual-Based Tests for

Cointegration in Panel Data. Journal of Econometrics, 90(1), 1-44. https://doi.org/10.1016/s0304-4076(98)00023-2;

[13]Kao, C. \& Chiang, M. (2000), On the Inference of A Cointegrating Regression in Panel Data. Advances in Econometrics, 15(1), 179-222;

[14]Karras, G. \& Stokes, H. H. (1999), Why Are the Effects of Money-Supply Shocks Asymmetric? Evidence From Prices, Consumption, and Investment. Journal of Macroeconomics, 21(4), 713-727. https://doi.org/10.1016/s01640704(99)80003-2;

[15]Levin, A., Lin, C. F., \& Chu, C. S. J. (2002), Unit Root Tests in Panel Data: Asymptotic and Finite-Sample Properties. Journal of Econometrics, 108(1), 1-24. https://doi.org/10.1016/s0304-4076(01)00098-7;

[16]Lucas Jr, R. E. (1972), Expectations and the Neutrality of Money. Journal of Economic Theory, 4(2), 103-124. https://doi.org/10.1016/0022-0531(72)90142-1; 
Tayfur Bayat, Seyhun Tutgun, Izzet Taşar

[17]Hofman, D. J., Atoyan, R. V., Tzanninis, D. \& Mecagni, M. (2007), The Duration of Capital Account Crises-An Empirical Analysis. IMF Working Papers, 1-42. https://doi.org/10.5089/9781451868210.001;

[18]Pill, H. (1997), Real Interest Rates and Growth: Improving on Some Deflating Experiences. The Journal of Development Studies, 34(1), 85-110. https://doi.org/10.1080/00220389708422504;

[19]Seth, A. K. \& Varma, S. (2007), Capital Flows and the Macro Economy: The Indian Experience. Journal of Nepalese Business Studies, 4(1), 62-74. https://doi.org/10.3126/jnbs.v4i1.1030; [20]Taylor, M. P. (1999), Real Interest Rates and Macroeconomic Activity. Oxford Review of Economic Policy, 15(2), 95-113. https://doi.org/10.1093/oxrep/15.2.95;

[21] Thoma, M. A. (1994), Subsample Instability and Asymmetries in MoneyIncome Causality. Journal of econometrics, 64(1), 279-306.

https://doi.org/10.1016/0304-4076(94)90066-3. 